\title{
Chromosomal localisation of a pseudoautosomal growth gene(s)
}

\author{
Tsutomu Ogata, Christine Petit, Gudrun Rappold, Nobutake Matsuo, \\ Takahiko Matsumoto, Peter Goodfellow
}

\begin{abstract}
Although recent molecular studies in patients with sex chromosome aberrations are consistent with a growth gene(s) being present in the pseudoautosomal region (PAR), the precise location has not been determined. In this report, we describe a Japanese boy and his mother with an interstitial deletion in Xp22.3 and review the correlation between genotype and stature in six cases of partial monosomy of the PAR. The results indicate that the region from DXYS20 to DXYS15 is the critical region for the putative growth gene(s).

(f Med Genet 1992;29:624-8)
\end{abstract}

Karyotype-phenotype analysis in patients with $\mathrm{X}$ chromosome rearrangements suggests the presence of a growth gene(s) at the tip of $\mathrm{Xp} .{ }^{1-3}$ In particular, Curry et $a l^{3}$ have shown that a deletion of $\mathrm{Xp22.32-pter} \mathrm{results} \mathrm{in} \mathrm{signi-}$ ficant short stature. Similar analysis of Y chromosome rearrangements is also consistent with a growth gene(s) being located at the tip of $Y p$, distal to the testis determining gene, TDF. ${ }^{14}$ As TDF has been shown to be equivalent to SRY and is located only $5 \mathrm{~kb}$ from the pseudoautosomal boundary, ${ }^{5}$ these results argue that the growth gene(s) resides in the pseudoautosomal region (PAR). The association between short stature and terminal deletions within the PAR has provided strong support for this localisation. ${ }^{6-8}$ However, the precise position of the growth gene(s) within the PAR has not been determined. Henke $e t a l$ have suggested that the growth gene(s) is located in the middle part of the PAR, on the basis of two patients analysed and two published cases. ${ }^{910}$ In contrast, Ogata et $a l^{8}$ have proposed that the growth gene(s) is present in the distal part of the PAR, based on the study of a subject with a terminal Xp deletion distal to DXYS15.

In this report, we describe a Japanese boy and his mother with an interstitial deletion in $\mathrm{Xp} 22.3$, and review the correlation between genotype and stature in six cases of partial monosomy of the PAR.

\section{Case report}

This 11 year old boy has previously been described as suffering from a contiguous gene syndrome involving $\mathrm{X}$ linked recessive chondrodysplasia punctata (CDPX) and steroid sulphatase (STS) deficiency. ${ }^{11}$ His clinical manifestations included nasal hypoplasia, short digits, and ichthyosis. The diagnosis of CDPX was established by the neonatal radio- graphs showing stippled calcifications of multiple epiphyseal centres. The diagnosis of STS deficiency was confirmed by the absence of STS activity in lymphocytes. Kallman syndrome was excluded by the lack of anosmia and hypogonadism. Mental retardation was equivocal. Biochemical studies and ophthalmological examinations were normal.

The parents and the younger brother were clinically normal. STS activity detected in the mother's lymphocytes was 110 pmol DHEA/ $\mathrm{h} / \mathrm{mg}$ protein (normal female value $227 \pm 64$ ), being consistent with heterozygosity for STS deficiency.

\section{Methods}

GROWTH ASSESSMENT

The heights of the patient and his brother were assessed by the cross sectional centile growth curve for normal Japanese boys based on the 1980 national survey. ${ }^{12}$ Target height $(\mathrm{TH}$, a child's final height as predicted from the parental height) and target range (TR, 95\% confidence interval of $\mathrm{TH}$ ) were obtained from the following equations for Japanese boys: $\mathrm{TH}=\{\mathrm{PH}+(\mathrm{MH}+13)\} / 2+2$ and $\mathrm{TR}=\mathrm{TH} \pm$ $9(\mathrm{~cm})$, where $\mathrm{PH}$ is paternal height and $\mathrm{MH}$ maternal height. ${ }^{13}$ The parental height was estimated by the age adjusted normal Japanese standards based on the annual growth survey of the Ministry of Education, to allow for the positive secular trend in the adult height of the Japanese. ${ }^{13}$

\section{CYTOGENETIC STUDIES}

Chromosome analysis was performed by $G$ banding ${ }^{14}$ on spreads from 40 peripheral blood lymphocytes. The fine structure of the $\mathrm{X}$ chromosome was examined by high resolution $G$ banding with ethidium bromide. ${ }^{15}$

\section{SOUTHERN BLOT ANALYSIS}

Genomic DNA was extracted from the peripheral leucocytes of the patient and his mother and from those of normal subjects. Southern transfer, probe hybridisation, and autoradiography were carried out by the standard methods. ${ }^{16}$ The genomic DNA was digested with EcoRI, HindIII, TaqI, and SstI, and hybridised with 13 probes defining loci in the terminal part of Xp (table 1). The copy number of each locus was determined by the pattern of restriction fragment length polymorphisms (RFLPs) or by the comparison of band intensity. Band intensity was measured by a laser densitometer (Ultroscan, LKB), using the autosomal TK gene $\mathrm{e}^{30}$ as an internal control. 
Table 1 Band intensity ratios as compared with the autosomal TK gene.

\begin{tabular}{|c|c|c|c|c|c|c|c|}
\hline Locus & Probe & Enzyme & Patient & Mother & Female & Male & Reference \\
\hline $\begin{array}{l}\text { Pseudoau } \\
D X Y S 14 \\
D X Y S 60 \\
D X Y S 28 \\
D X Y S 59 \\
D X Y S 15 \\
C S F 2 R A \\
D X Y S 17 \\
M I C 2\end{array}$ & $\begin{array}{l}\text { nal region } \\
29 \mathrm{C1} \\
\text { U7A } \\
\text { pDP411 } \\
68 \mathrm{~A} \\
113 \mathrm{D} \\
\text { cDNA } \\
601 \\
\text { 19B }\end{array}$ & $\begin{array}{l}\text { HindIII } \\
\text { HindIII } \\
\text { EcoRI } \\
\text { EcoRI } \\
\text { EcoRI } \\
\text { HindIII } \\
\text { HindIII }\end{array}$ & $\begin{array}{l}- \\
0.39 \\
1.60 \\
1.25 \\
1.22 \\
0.93 \\
0.71 \\
0.65\end{array}$ & $\begin{array}{l}- \\
0.43 \\
1.78 \\
1.30 \\
1.32 \\
1.20 \\
0.77 \\
0.70\end{array}$ & $\begin{array}{l}- \\
0.43 \\
1.70 \\
1.20 \\
1.15 \\
0.88 \\
1.52 \\
1.43\end{array}$ & $\begin{array}{l}- \\
0.45 \\
1.85 \\
1.33 \\
1.35 \\
1.10 \\
1.55 \\
1.48\end{array}$ & $\begin{array}{l}17 \\
18 \\
19 \\
20 \\
21 \\
22 \\
23 \\
24\end{array}$ \\
\hline $\begin{array}{l}\mathrm{X} \text { specific } \\
P A B X \\
D X S 31 \\
S T S \\
D X S 143 \\
D X S 69\end{array}$ & $\begin{array}{l}\text { on } \\
\text { Hfo.2 } \\
\text { M1A } \\
\text { ST-12 } \\
\text { dic56 } \\
71-7 A\end{array}$ & $\begin{array}{l}\text { SstI } \\
\text { EcoRI } \\
\text { EcoRI } \\
\text { EcoRI } \\
\text { HindIII }\end{array}$ & $\begin{array}{l}0 \\
0 \\
0 \\
0 \cdot 32 \\
0 \cdot 85\end{array}$ & $\begin{array}{l}0.58 \\
0.87 \\
0.84 \\
0.65 \\
1.60\end{array}$ & $\begin{array}{l}1 \cdot 20 \\
1 \cdot 60 \\
1 \cdot 70 \\
0 \cdot 70 \\
1 \cdot 78\end{array}$ & $\begin{array}{l}0.61 \\
0.90 \\
0.91 \\
0.37 \\
0.80\end{array}$ & $\begin{array}{l}25 \\
26 \\
27 \\
28 \\
29\end{array}$ \\
\hline
\end{tabular}

The loci are arranged from telomere to centromere. Non-RFLP bands were measured for the band intensity. For DXYS14, only RFLP bands were detected. Dosage blottings for $D X Y S 59, C S F 2 R A, D X Y S 17, M I C 2, D X S 31, S T S$, and $D X S 143$ are shown in fig 2.

PCR ANALYSIS

PCR (polymerase chain reaction) analysis for the pseudoautosomal boundary $(P A B X \mid$ $P A B Y)^{31}$ was performed on genomic DNA of the patient under standard conditions. ${ }^{16} \mathrm{Re}-$ actions were cycled 30 times with incubations at $94^{\circ} \mathrm{C}$ for one minute, at $54^{\circ} \mathrm{C}$ for one minute, and at $72^{\circ} \mathrm{C}$ for two minutes. Primer sequences used were: pseudoautosomal, 5'-GAATTCTTAACAGGACCCATTTAGGATTAA-3'; $\mathrm{X}$ specific, 5'-CTGCAGAAACAAGCTCATCAGCGTGACTAT-3'; and Y specific, 5'GTACTACCTTTAGAAAACTAGTATTTTCCC-3'.

\section{Results}

GROWTH ASSESSMENT

The growth charts of the patient and his brother are shown in fig 1 , together with their TH/TR. The height of the patient remained between the 10 th and 25 th centile (mean $-1 \cdot 1 \mathrm{SD})$, and that of the brother was around the 50 th centile (mean $+0.3 \mathrm{SD}$ ). The 37 year old father measured $168 \mathrm{~cm}$ (mean $+0.2 \mathrm{SD}$, male standard for his age $166.8 \pm 5.6 \mathrm{~cm}$ ) and the 31 year old mother $158 \mathrm{~cm}$ (mean $+0.4 \mathrm{SD}$, female standard for her age $156.0 \pm 4.9 \mathrm{~cm}$ ). Thus TH was $171.5 \mathrm{~cm}$ (mean $+0.3 \mathrm{SD}, 1980$ male standard $169.7 \pm 5.6 \mathrm{~cm}$ )

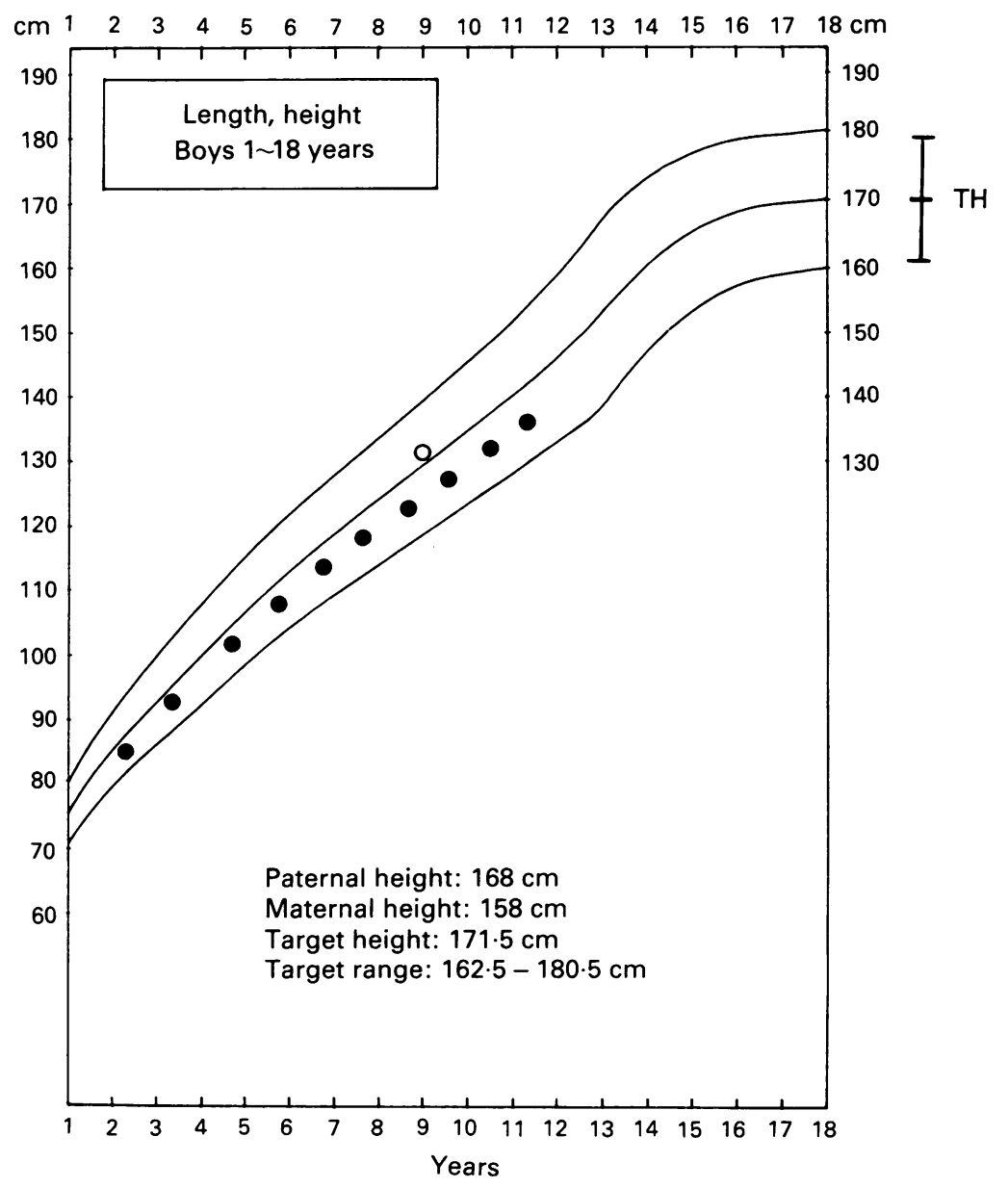

Figure 1 The growth charts of the patient (closed circles) and the brother (open circle). The upper, middle, and lower curves depict the 97th, 50th, and 3rd centile growth curves of fapanese boys, respectively. 
and TR 162.5 180.5 cm (mean - 1.3 SD TaqI digests), DXYS15 (TaqI digests), and mean $+1.9 \mathrm{SD}$ ). The two sisters of the mother $C S F 2 R A$ (the gene locus for the receptor for were $156 \mathrm{~cm}$ and $152 \mathrm{~cm}$ tall.

CYTOGENETIC STUDIES the granulocyte-macrophage colony stimulating factor) (HindIII and TaqI digests) recognised bands specific to the patient and bands shared by the patient and his mother. The The patient's karyotype was 46,XY. No struc- probe defining DXYS17 (TaqI digests) failed tural abnormality of the $\mathrm{X}$ chromosome was to show a common band between the patient detected by high resolution $\mathrm{G}$ banding. and his mother. Comparison of band intensity for probe-enzyme combinations which failed to detect RFLPs indicated that, in both the SOUTHERN BLOT ANALYSIS patient and the mother, $D X Y S 60, D X Y S 28$,

Representative results are shown in fig 2 and $D X Y S 59, D X Y S 15$, and CSF2RA in the table 1. Probes defining DXYS14 (EcoRI and distal part of the PAR were present in two

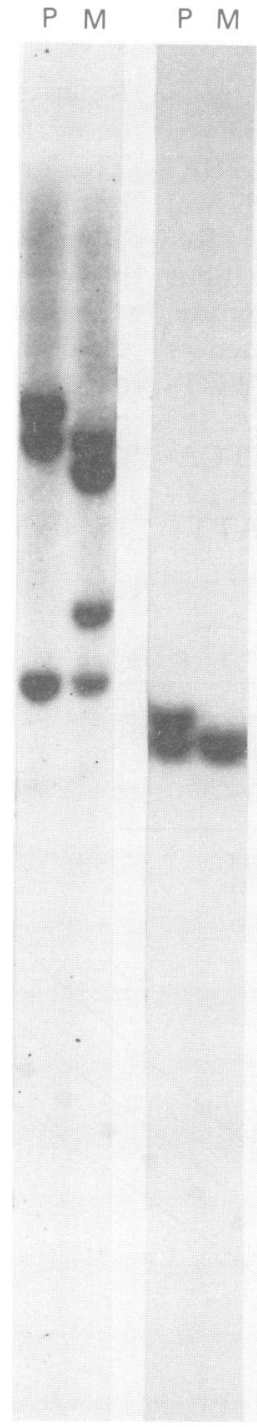

[1]
$[2]$

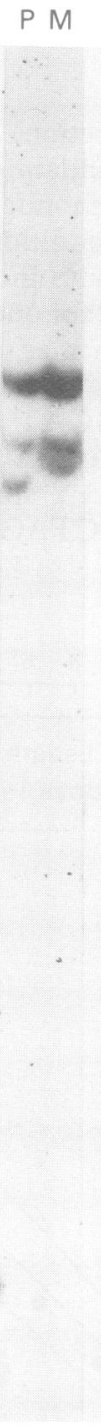

[3]

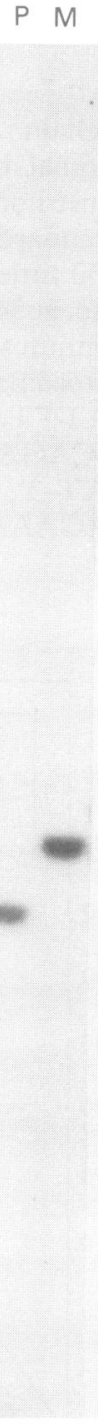

$[4]$
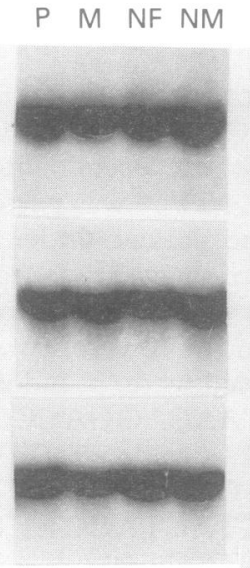

[5]
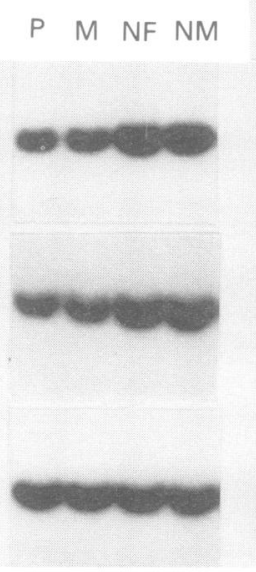

[6]

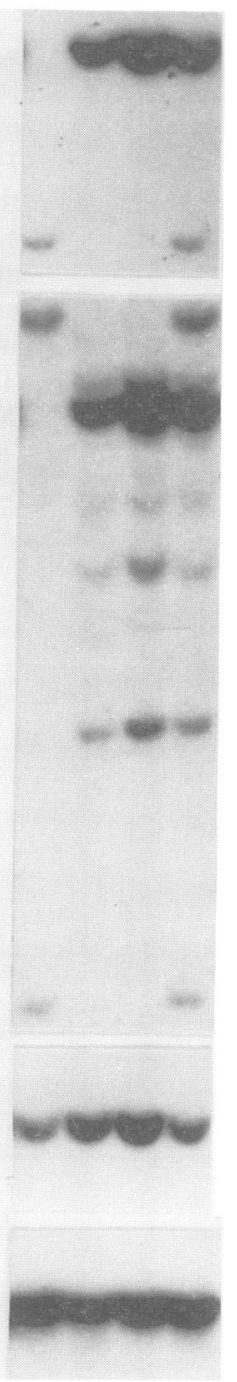

7]

Figure 2 Southern blot analysis ( $P=$ patient, $M=$ mother, $N F=$ normal female, NM= normal male). (1) EcoRI digests hybridised with 29C1 (DXYS14). (2) TaqI digests hybridised with $113 D$ (DXYS15). (3) HindIII digests hybridised with cDNA probe for GM-CSF receptor gene (CSF2RA). (4) TaqI digests hybridised with 601 (DXYS17). (5) EcoRI digests hybridised with 68A (DXYS59, top panel), cDNA probe for GM-CSF receptor gene (CSF2RA, middle panel), and the probe for autosomal TK gene (bottom panel) (same filter). (6) HindIII digests hybridised with 601 (DXYS17, top panel), 19B (MIC2, middle panel), and the probe for autosomal TK gene (bottom panel) (same filter). (7) EcoRI digests hybridised with $M 1 A$ (DXS31, top panel), ST-12 (STS, second panel), dic56 (DXS143, third panel), and the probe for autosomal TK gene (bottom panel) (same filter). RFLP pattern and comparison of band intensity indicate that, in both the patient and his mother, $D X Y S 14, D X Y S 59, D X Y S 15$, and CSF2RA in the distal part of the

pseudoautosomal region are present in double doses, whereas a single dose is detected for $D X Y S 17$ and MIC2 in the proximal part of the pseudoautosomal region. DXS31 and $S T S$ in the $X$ specific region are absent in the patient and present in a single copy in the mother. 
copies, whereas only a single copy was detected for $D X Y S 17$ and $M I C 2$ in the proximal part of the PAR. The $\mathrm{X}$ specific loci from $P A B X$ to $S T S$ were absent in the patient and present in a single copy in the mother.

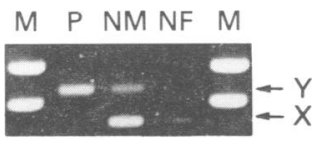

Figure 3 PCR analysis of the pseudoautosomai boundary $(M=D N A$ size marker, $P=$ patient $N M=$ normal male $N M=$ normal female) The $X$ specific product $(771 \mathrm{bp})$ is absent in the patient, although the $Y$ specific product ( $947 \mathrm{bp}$ ) is present. The size markers represent 1.08 and $0.87 \mathrm{~kb}$ $\Phi X 174 /$ HaelII fragments.

No trace of $P A B X$ was detected in the patient of a normal $\mathrm{X}$ chromosome (fig 3). $P A B Y$ was present as expected.

\section{Discussion}

The present study indicates that the patient inherited, from his mother, a submicroscopic interstitial deletion with breakpoints between CSF $2 R A$ and DXYS17 and between STS and $D X S 143$. Although the deletion explains the CDPX and STS deficiency of the patient, ${ }^{69}$ it is not associated with short stature.

\section{PCR ANALYSIS} providing additional evidence for the absence The patient's height is within the normal range of Japanese boys and appropriate for the TH/ TR, despite the CDPX. The mother's height is above the average height of Japanese females of her age. In addition, the normal brother's height is in close agreement with the TH/TR calculated using the mother's height. This suggests that the putative pseudoautosomal growth gene(s) is present in the region distal to DXYS17 and preserved in the abnormal $\mathrm{X}$ chromosome of the patient and his mother.

For a more precise localisation of the growth gene(s), it is useful to review the correlation between genotype and stature in cases of partial monosomy of the PAR; six cases have previously been published (table 2 ).

The critical factor is adequate height assessment (table 3). Cases 1 and 2 are estimated to be short not only by comparison with population standards but also by comparison with

Table 2 Reported cases of partial monosomy of the pseudoautosomal region.

\begin{tabular}{|c|c|c|}
\hline Case & Karyotype & Reference \\
\hline $\begin{array}{ll}1 & \text { Sporadic } \\
2 & \text { Sporadic } \\
3 & \text { Familial } \\
4 & \text { Sporadic } \\
5 & \text { Sporadic } \\
6 & \text { Familial }\end{array}$ & $\begin{array}{l}\text { 46,X,rea }(X)(X q t e r \rightarrow X q 26:: X p 22.3 \rightarrow X q 26:) \\
\text { 46,X,t(X;Y)(Xqter } \rightarrow X p 22.3:: Y p 11 \rightarrow \text { Yqter }) \\
\text { 46,XX }(n=1) \text { and 46,XY }(n=1) \\
\text { 46,X,t(Y;22) (p11.2; } 11) \\
\text { 45,X/46,X,psu dic }(X)(X q t e r \rightarrow X p 22.3:: X p 22.3 \rightarrow X q t e r) \\
\text { 46,XX }(n=4) \text { and 46,XY }(n=1)\end{array}$ & $\begin{array}{c}8 \\
6,7 \\
\text { Present case } \\
10 \\
7 \\
9\end{array}$ \\
\hline
\end{tabular}

Cases 3 and 6 have a submicroscopic interstitial deletion in $\mathrm{Xp22.3.}$
TH/TR. The latter comparison is useful in the assessment of individual height, since it is primarily determined by the genetic height potential as represented by parental height. ${ }^{3336}$ Furthermore, the size of the height decrease found in case $1(14.5 \mathrm{~cm})$ and case $2(11 \mathrm{~cm})$ is similar to the adult height difference between 13 females with $46, \mathrm{X}, \operatorname{del}(\mathrm{X})(\mathrm{p} 22.32)$ and nine females with $46, \mathrm{XX}$ in the two pedigrees described by Curry et $a l^{\beta}$ (about $12 \mathrm{~cm}$ ). This is consistent with the growth gene(s) being affected and present in a single dose in the two cases. The normal stature of case 3 (the present case) is as described above. Cases 4 and 5 appear normal in height, although $\mathrm{TH} / \mathrm{TR}$ is not available. Classification of case 6 is more difficult. The male patient is shorter than the two normal brothers and his height is below the normal range of French males, but this could be because of the CDPX. The four carrier females in the pedigree are short, but their heights are within the normal range of French females. Unfortunately, TH/TR is not available for the family.

Correlation of genotype with stature in the six cases is shown in fig 4 (the dosage of $C S F 2 R A$ in cases 1,2 , and 6 and that of DXYS15 in case 6 are unpublished data). The simplest explanation is to postulate a single growth gene in the region between the breakpoints of cases 1 and 5, and to assume that case 6 is free from pathological short stature in the context of the growth gene. The distal and proximal limits of the region are defined by DXYS20 and DXYS15, respectively. It might be possible that the growth gene extends proximally and is disrupted in case 1 , and even in case 2 . In this case, the growth gene is located distal to $D X Y S 17$ because of normal height in cases 3 and 4 . Furthermore, unless the growth gene overlaps with $C S F 2 R A$, it must be located distal to $C S F 2 R A$. Although case 6 may be associated with pathological short stature, a simple explanation in terms of genotype-phenotype correlation is impossible because of the absence of a shared deleted region between case 6 and cases 1 and 2 .

This location of the growth gene is inconsistent with that previously suggested by Henke et $a l$ on the basis of the genotype-phenotype analysis of cases $2,4,5$, and 6 . The discrepancy is apparently caused by the difference in the assessment of case 6: Henke et al regarded

Table 3 Height assessment for subjects with partial monosomy of the pseudoautosomal region.

\begin{tabular}{|c|c|c|c|c|c|c|c|c|}
\hline No* & Sex & $\begin{array}{l}\text { Age } \\
(\mathrm{y})\end{array}$ & $\begin{array}{l}\text { Height } \\
(\mathrm{cm})\end{array}$ & Remark & $\begin{array}{l}\text { Comparison with } \\
\text { population standards }\end{array}$ & $\begin{array}{l}\text { Comparison } \\
\text { with TH/TR }\end{array}$ & $\begin{array}{l}\text { Heights of } \\
\text { normal relatives }\end{array}$ & Assessment \\
\hline 1 & $\mathrm{~F}$ & $9 \cdot 8$ & 122 & & $<3$ rd centile & Shortt & \multirow[t]{2}{*}{ Brother 75 th-90th centile } & Short \\
\hline 2 & $\mathbf{M}$ & 33 & 155 & & $<3$ rd centile $\ddagger$ & Short§ & & Short \\
\hline 3 & $\begin{array}{l}\mathbf{M} \\
\mathbf{F}\end{array}$ & $\begin{array}{l}11 \cdot 3 \\
31\end{array}$ & $\begin{array}{l}136 \\
158\end{array}$ & CDPX & $\begin{array}{l}-1.1 \mathrm{SD} \\
+0.4 \mathrm{SD}\end{array}$ & $\begin{array}{l}\text { Normal } \\
\text { NA }\end{array}$ & \multirow[t]{2}{*}{ Brother $+0.3 \mathrm{SD}$} & Normal \\
\hline 4 & $\mathbf{F}$ & $15 \cdot 8$ & 165 & & Normal for XYGD & $\mathrm{NA}$ & & Normal? \\
\hline 5 & $\mathbf{F}$ & 6.5 & 114 & Mosaic & 25 th- 50 th centile & NA & \multirow{3}{*}{$\begin{array}{l}\text { Mother 10th centile+ } \\
(155 \mathrm{~cm}) \\
\text { Brothers }-0.5 \\
\text { SDT }(172 \mathrm{~cm}) \text { and } \\
+1.6 \text { SD }(185 \mathrm{~cm})\end{array}$} & Normal? \\
\hline \multirow[t]{2}{*}{6} & $\mathbf{M}$ & Adult & 160 & CDPX & -2.5 SDT & NA & & \multirow[t]{2}{*}{ Equivocal } \\
\hline & $\mathbf{F}$ & Adult & $152 \sim 155$ & $\mathrm{n}=4$ & $-2.0 \mathrm{SD} \sim-1.5 \mathrm{SD} \pi$ & NA & & \\
\hline
\end{tabular}

$\mathrm{TH}=$ target height, $\mathrm{TR}=$ target range, $\mathrm{NA}=$ not available, $\mathrm{CDPX}=\mathrm{X}$ linked chondrodysplasia punctata, $\mathrm{XYGD}=\mathrm{XY}$ gonadal dysgenesis.

* The case numbers correspond to those in table 2 .

† Predicted adult height based on the biological data of this patient $(148.5 \mathrm{~cm})$ is below her TH $(163 \mathrm{~cm})$ and TR $(155-171 \mathrm{~cm}) .^{8}$

+ According to the height standards of Tanner et al. ${ }^{32}$

$\S$ According to Tanner's formula, ${ }^{33}$ TH of this patient is $166 \mathrm{~cm}$ and TR $156-176 \mathrm{~cm}$

| The mean height of adult Caucasian patients (20 to 50 years of age) with XYGD is $172.0 \pm 7.0 \mathrm{~cm} .{ }^{34}$

$\pi$ French height standard is $163.3 \pm 5.6 \mathrm{~cm}$ for females and $175 \cdot 2 \pm 6.0 \mathrm{~cm}$ for males. ${ }^{35}$ 


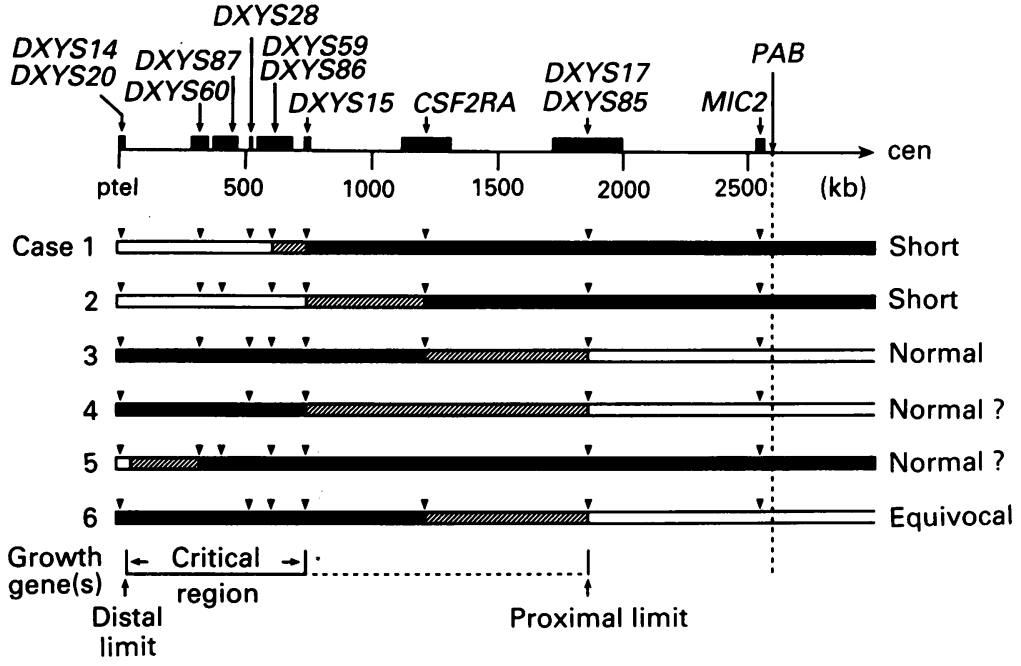

Figure 4 A diagram showing the genotype-phenotype correlations in six cases of partial monosomy of the pseudoautosomal region. The case numbers correspond to those in tables 2 and 3. The white areas denote the monosomic regions and the black areas the disomic or trisomic regions. The striped areas depict the dosage unknown regions where the breakpoints should exist. For case 5 with $45, X / 46, X$, dic $(X)$ mosaicism, the genotype of cells with the abnormal $X$ chromosome is shown. The inverted black triangles represent the loci examined in each case. Dosage of CSF2RA in cases 1, 2, and 6 and that of DXYS15 in case 6 are unpublished data. The two doses of CSF2RA in case 1 have been confirmed by RFLP pattern using parental DNA. The two doses of CSF2RA in case 2 have been based on densitometric analysis. The two doses of DXYS15 and CSF2RA in case 6 have been established by the positive bands detected for DNA from a human-rodent hybrid cell line in which the abnormal $X$ chromosome of the patient is retained but the $Y$ chromosome is absent. The physical positions of the pseudoautosomal loci are based on the reports of Petit et al, ${ }^{20}$ Brown, ${ }^{37}$ Henke et al, ${ }^{7}$ and Rappold et al ${ }^{38}$ DXYS14 is just distal to DXYS20, but the relative position is unknown between DXYS59 and DXYS86 and between DXYS17 and DXYS85. The critical region for the pseudoautosomal growth gene $(s)$ is indicated, together with the distal and proximal limits.

case 6 as having pathological short stature owing to the impairment of the growth gene(s), as described in the original paper. ${ }^{9}$ In addition, cases 1 and 3 were not available at that time, nor was the dosage of $C S F 2 R A$ analysed.

In summary, although genotype-phenotype analysis of the pseudoautosomal growth gene(s) is still not conclusive, we propose that the region between $D X Y S 20$ and $D X Y S 15$ is the critical region for the growth gene(s) and that $D X Y S 17$ defines the proximal limit of the whole growth gene(s). Further accumulation of informative cases will permit a more precise localisation.

We would like to thank Drs Nicholas Gough and Andrea Ballabio for providing the cDNA probe for GM-CSF receptor gene and the probe ST-12, respectively. This work was supported by MRT (grant 90.C.0518), CNRS (grant URA 1445), and DFG Ra 380/3-2.

1 Simpson JL. Gonadal dysgenesis and abnormalities of the human sex chromosomes: current status of phenotypekaryotype correlations. Birth Defects 1975;11:23-59.

2 Goldman B, Polani PE, Daker MG, Angell RR Clinica and cytogenetic aspects of X-chromosome deletions. Clin and cytogenetic aspect $1982 ; 21: 36-52$

3 Curry CJR, Magenis RE, Brown M, et al. Inherited chondrodysplasia punctata due to deletion of the terminal short arm of an X chromosome. $N$ Engl $\mathcal{f}$ Med 1984; 311:1010-5.

4 Buhler EM. A synopsis of the human Y chromosome. Hum Genet 1980;55:145-75.

5 Goodfellow PN, Hawkins JR, Sinclair AH. Cloning the mammalian sex-determining gene, TDF. In: Genome mammalian sex-determining gene, TDF. In: Genome analysis. Vol 3. Genes and phenotypes. New

6 Ballabio A, Bardoni B, Carrozzo R, et al. Contiguous gene syndromes due to deletions in the distal short arm of the human $\mathrm{X}$ chromosome. Proc Natl Acad Sci USA 1989;86:10001-5.
7 Henke A, Wapenaar M, van Ommen G-J, Maraschio P, Camerino G, Rappold G. Deletions within the pseudoautosomal region help map three new markers and indicate possible role of this region in linear growth. $\mathrm{Am} \mathcal{f} \mathrm{Hum}$ Genet 1991;49:811-9.

8 Ogata T, Goodfellow P, Petit C, Aya M, Matsuo N. Short stature in a girl with a terminal Xp deletion distal to DXYS15: localisation of a growth gene(s) in the pseudoautosomal region. $\mathcal{F}$ Med Genet 1992;29:455-9.

9 Petit C, Melki J, Levilliers J, Serville F, Weissenbach J, Maroteaux P. An interstitial deletion in Xp22.3 in family with $\mathrm{X}$-linked recessive chondrodysplasia punctata family with X-linked recessive chondrodysplasia

10 Page DC, Fisher EMC, McGillivray G, Brown LG. Additional deletion in sex-determining region of human $Y$ chromosome resolves paradox of $\mathrm{X}, \mathrm{t}(\mathrm{Y} ; 22)$ female. Nature 1990;346:279-81.

11 Nishimura S, Masuda H, Matsumoto T, Sakura N, Matsumoto $T$, Ueda $K$. Two cases of steroid sulfatase deficiency with complex phenotype due to contiguous gene deletions. Am ₹ Med Genet 1991;40:260-3.

12 Tsuzaki S, Matsuo N, Osano M. The physical growth of Japanese children from birth to 18 years of age. Helv Paediatr Acta 1987;42:111-9.

13 Ogata T, Matsuo N, Tamai S, Osano M, Tango T. Target height and target range for the Japanese. Acta Paediat fpn 1990;94:1535-40.

14 Seabright $M$. Improvement of trypsin method for banding chromosomes. Lancet 1973;i:1249-50.

15 Ikeuchi $T$. Inhibitory effect of ethidium bromide on mitotic chromosome condensation and its application to highchromosome condensation and its application to high1984;38:56-61.

16 Sambrook J, Fritsch EF, Maniatis T. Molecular cloning. 2nd ed. New York: Cold Spring Harbor Laboratory Press, 1989.

17 Cooke HJ, Brown WRA, Rappold GA. Hypervariable telomeric sequences from the human sex chromosomes are pseudoautosomal. Nature 1985;317:687-92.

18 Rouyer F, Simmler M-C, Page DC, Weissenbach J. A sex chromosome rearrangement in a human XX male caused by Alu-Alu recombination. Cell 1987;51:417-25.

19 Page DC, Bieker K, Brown LG, et al. Linkage, physical mapping and DNA sequence analysis of pseudoautosomal loci on the human $\mathrm{X}$ and $\mathrm{Y}$ chromosomes. Genomics 1987;1:243-56.

20 Petit C, Levilliers J, Weissenbach J. Physical mapping of the human pseudoautosomal region: comparison with genetic linkage map. $E M B O$ f 1988;8:2369-76.

21 Simmler MC, Rouyer F, Vergnaud G, et al. Pseudoautosomal DNA sequences in the pairing region of the human sex chromosomes. Nature 1985;317:692-7.

22 Gough NM, Gearing DP, Nicola NA, et al. Localization of the human GM-CSF receptor gene to the X-Y pseudoautosomal region. Nature 1990;345:734-6.

23 Rouyer F, Simmler MC, Johnsson C, Vergnaud G, Cooke HJ, Weissenbach J. A gradient of sex linkage in the pseudoautosomal region of the human sex chromosomes. Nature 1986;319:291-5.

24 Goodfellow PJ, Darling SM, Thomas NS, Goodfellow PN. A pseudoautosomal gene in man. Science 1986;234:740-3.

25 Ellis NA, Goodfellow PJ, Pym B, et al. The pseudoautosomal boundary in man is defined by an Alu repeat sequence inserted on the Y chromosome. Nature 1989;337:81-4.

26 Koenig M, Camerino G, Heilig R, Mandel JL. A DNA fragment from the human $\mathrm{X}$ chromosome short arm which detects a partially homologous sequence on the $\mathrm{Y}$ chromosome long arm. Nucleic Acids Res 1984;12:4097109.

27 Ross MT, Ballabio A, Craig IW. Long range physica mapping around the human steroid sulfatase locus. Genomics 1990;6:528-39.

28 Middlesworth W, Bertelson C, Kunkel LM. An RFLP detecting single copy $\mathrm{X}$-chromosome fragment, dic56, from Xp22-Xpter. Nucleic Acids Res 1985;13:5723.

29 Kunkel LM Tantravahi U, Kurnit DM Eisenhard M Bruns GP, Latt SA. Identification and isolation of transcribed human X chromosome DNA sequences. Nucleic scribed human X chromoso

$30 \mathrm{Lau}$ YF, Kan YW. Direct isolation of the functional human thymidine kinase gene with a cosmid shuttle vector. Proc Natl Acad Sci USA 1984;81:414-8.

31 Ellis N, Taylor A, Bengtsson BO, Kidd J, Rogers J, Goodfellow P. Population structure of the human pseudoautosomal boundary. Nature 1990;344:663-5.

32 Tanner JM, Whitehouse RH, Takaishi M. Standards from birth to maturity for height, weight, height velocity and weight velocity: British children, 1965. Arch Dis Child 1966;41:454-71 (part I), 1966;41:613-35 (part II).

33 Tanner JM. Use and abuse of growth standards. In: Falkner F, Tanner JM, eds. Human growth. 2nd ed. New York: Plenum, 1985:95-109.

34 Ogata T, Matsuo N. Comparison of adult height between patients with XX and YX gonadal dysgenesis: support for a Y specific growth gene(s). F Med Genet 1992;29:539-41.

Sempe M, Pedron G, Roy-Pernot MP. Auxologie: methode et sequences. Paris: Theraplix, 1979.

36 Mueller WH. The genetics of size and shape in children and adults. In: Falkner F, Tanner JM, eds. Human growth. 2nd ed. New York: Plenum, 1985:145-68.

37 Brown WRA. A physical map of the human pseudoautosomal region. EMBO $\mathcal{f} 1988 ; 7: 2377-85$.

38 Rappold GA, Henke A, Klink A, et al. Patients with deletions within the pseudoautosomal region help map 13 new pseudoautosomal probes. Cytogenet Cell Genet 1991;58:2083. 